\title{
Download
}

UDC 711.25 https://doi.org/10.17721/2308-135X.2021.61.29-37

Syvak Oksana Olegovna, PhD in Geographic sciences State Enterprise Ukrainian State Scientific-Research Institute of Urban Design «Dipromisto» named after Y.M.Bilokon, Kyiv, Ukraine, e-mail: syvak_ok@ukr.net

\section{REFLECTION OF PROSPECTS OF RECREATION AND TOURISM DEVELOPMENT IN THE BORDER TERRITORIES OF UKRAINE AND POLAND IN THE INTEGRATED SPATIAL STRATEGY}

The aim of the article is research related to the directions and prospects of recreation and tourism in the border areas of Ukraine and Poland (spatial dimension), which are reflected in the project of spatial planning - an integrated strategy for spatial development of Ukraine and Poland. Integrated spatial development strategy - a strategy for the development of the territory, which includes the solution of individual sectoral tasks and the construction of a comprehensive scenario for a certain period. This study identifies and presents the prerequisites and measures necessary for the development of the recreational and tourist industry in the border areas - the spatial-territorial aspect.

Methods of research and solution of the tasks were carried out on the basis of generalization and integration of general scientific methods, analysis and synthesis, expert method, methodology of constructive geography and spatial planning. In the course of the research SWOT analysis, methods of functional zoning of the territory and graphic modeling were used.

The results of the work reflected in this article will contribute to the development of the recreational and tourism industry, based on the principles of ecologically balanced, sustainable development, which are determined on the basis of functional zoning of border areas, taking into account the results of SWOT analysis. The presented developments clearly illustrate that the rational organization of the territory, definition of framework conditions and modes of use, 
first of all, from calculations of ecological and resource possibilities and features of the territory in spatial planning projects is an indisputable and unalterable basis for further development of territories. As a result of the study, the definition of further development of the recreational and tourist industry as a priority for these areas is substantiated.

The scientific novelty lies in the importance and necessity of developing spatial planning projects (urban planning) for the rational organization of the territory and the use of available resources, and in this study it is for the development of the recreational and tourist industry in border areas. Reflecting the importance and relevance of the development of this industry in the territorial, environmental and economic dimensions, as well as determining the framework conditions and modes of use of territories.

The practical significance of the study lies in the use of its results for ecologically balanced territorial development of the recreational sphere of the border areas of Ukraine and Poland. The functional types of tourist-recreational territories are determined according to the "rigidity" of town-planning regulations and specialization, the basic decisions on creation of connections, knots, zones of possible cross-border activity are outlined, the hierarchical system of tourist-recreational territories is ordered.

Keywords: integrated strategy of spatial development, recreational and tourist industry, spatial planning, cross-border cooperation in the spatial dimension.

References

1. Aliêva A. Û. Strategičnì zavdannâ rozvitku ranskordonnogo rinku turistično-rekreacìjnih poslug / A. Û. Aliêva // Naukovij vìsnik Užgorodskogo universitetu. Serìa: Ekonomìka. - 2016. Vip. 1(2). - S. 99-101.

2. Analìz mižnarodnogo dosvìdu ta rozrobka spìlnogo proektu mìstobudìvnogo rozvitku transkordonnogo regìonu Ukraïna - Polŝa. - K.: Dipromìsto, 2012. - 31. s.;

3. Û.N.Bìlokon, V.V.Vladimirov, İ.A.Fomìn «Organìzaciâ teritoriì prikordonnih regìonìv 
(konceptualnì položennâ)» Monografîa/ Û.N.Bìlokon, V.V.Vladimirov, İ.A.Fomìn - K.: KNUSA, 2002. - 88 s.;

4. Goblik V.V. «Formuvannâ transkordonnih turističnih klasterìv âk prìoritetnij aprâm rozvitku prikordonnih regìonìv Ukraïni» / V. V. Goblik // Ekonomičnij forum. - 2015. - \# 3. - S. 117-123.;

5. Kujbìda V.S, Negoda V.A., Tolkovanov V.V. «Regìonalnij rozvitok ta prostorove planuvannâ teritoriï: dosvìd Ukraïni ta ìnših deržav-členìv Radi Êvropi: zbìrnik normativno-pravovih aktìv ì naukovo-analitičnih materìalìv z pitan regìonalnogo rozvitku ta prostorovogo planuvannâ». / V. S. Kujbìda, V. A. Negoda, V. V. Tolkovanov, Akademìa munìcipalnogo upravlìnnâ, Centr doslìdžen pitan regìonalnogo ì mìscevogo rozvitku ta spriânnâ admìnìstrativnìj reformì, Vseukraïnska Asocìaciâ magìstrìv deržavnogo upravlìnnâ, Ukraïnska asocìaciâ mìscevih ì regionalnih vlad. -Kiïv, Vidavnictvo «Kramar», 2009. -170 s.

6. Metodika rozroblennâ proektìv planuvannâ ta mìstobudìvnogo rozvitku ranskordonnih teritorìj ì transportno-komunìkacìjnih koridorìv Ukraïni. - K.: Dipromìsto, 2003 - 35 s.;

7. Û.Mìguŝenko «Transkordonnij turizm miž Ukraïnoû ta Polŝeû: stan, problemi ta perspektivi», Regìonalnij filìal Nacìnalnogo ìnstitutu strategičnih doslìdžen, «Vìsnik Lvìvskogo unìversitetu. Serîa mižnarodnì vìdnosini», vipusk 38, Lvìv 2016

8. Olga Kobelka «Ekologìcnij turizm âk prìoritetnij naprâmok stalogo turizmu v mežahnacìnalnih parkìv», Naukovì zapiski Ternopilskogo nacìnalnogo pedagogičnogo unìversitetu ìmenì Volodimira Gnatûka. Serîâ: Geografiâ. - 2010. - Vip.1(27). - S.400-405.;

9. Informator o badaniach i opraco waniach dotyczą cychobszarów transgranicznych. Інорорматор про статистичні спостереження та видання, присвячені транскордонним територіям, Warszawa, Rzeszów 2018;

10. Sławomir Sobotka A proposal for a tourism regionalization of Poland base dont he highest levels of tourismin a region, Tourism 2014, 24/2 
11. Shema planuvannâ teritoriï Volinskoï oblastì (DP «DìPROMìSTO», Kiïv, 2010).

12. Shema planuvannâ teritoriï Lvìvskoï oblastì (DP «DìPROMìSTO», Kiïv, 2009).

13. Shema planuvannâ teritoriï Zakarpatskoï oblastì (DP «DìPROMìSTO», Kiïv, 2011). 